\title{
A MUTAGENICITY AND CYTOTOXICITY STUDY ON LIMONIUM EFFUSUM AQUEOUS EXTRACTS BY ALLIUM, AMES AND MTT TESTS
}

\author{
Y. EREN ${ }^{1}$, A. ÖZATA ${ }^{2}$, M. KONUK ${ }^{3}$, D. AKYIL ${ }^{4}$, R. LIMAN ${ }^{5}$ \\ ${ }^{1}$ Department of Science Education, Faculty of Education, Süleyman Demirel University, Isparta, Turkey \\ ${ }^{2}$ Department of Biology, Faculty of Science, Anadolu University, Eskişehir, Turkey \\ ${ }^{3}$ Department of Molecular Biology and Genetics, Faculty of engineering and Natural Sciences, Üsküdar University, Istanbul, Turkey, \\ ${ }^{4}$ Department of Biology, Faculty of Science and Arts, Afyon Kocatepe University, Turkey, \\ ${ }^{5}$ Department of Molecular Biology and Genetics, Faculty of Science and Arts, Uşak University, Turkey \\ E-mail: ysneren@gmail.com
}

\begin{abstract}
Nowadays plants or plant extracts have become very important for alternative medicine. Plants and their extracts have many therapeutical advantages but some of them are potentially toxic, mutagenic, carcinogenic and teratogenic. Root, stem and leaf parts of Limonium effusum were used in this study and this species is an endemic species for Turkey. Mutagenic and cytotoxic effects of root, stem and leaf aqueous extracts were observed with Allium, Ames and MTT tests. Allium root growth inhibition test and mitotic index studies showed that aqueous extracts have dose-dependent toxic effects. Chromosome aberration studies indicated that especially sticky chromosome, anaphase-telophase disorder and laggard chromosome anomalies were highly observed. Ames test performed with Limonium effusum root aqueous extracts, showed weak mutagenic effects in Salmonella typhimurium TA98 strain with S9. MTT test based on mitochondrial activity indicated that most of the aqueous extracts have cytotoxic effects. This study aimed to determine the possible mutagenic and cytotoxic effects of L. effusum aqueous extracts by using bacterial, plant and mammalian cells. This research showed that some low concentrations of the L. effusum extracts have inhibited cytotoxic effects but high concentrations have induced cytotoxicity. On the other hand only a weak mutagenic activity was identified by Ames test with TA98 S9(+).
\end{abstract}

Key words: Limonium effusum, Allium test, Ames test, MTT test.

Introduction. In these days products of plants and their extracts usage have been increasing but this is creating some problems. These products may have positive effects but their unconscious usage is increasing quickly. So toxic and mutagenic effects of these products become unavoidable.

Phytotherapy have been used all over the world, especially some countries applicate systematical and complicated phytotherapy methods. Nowadays usage of phytotherapic methods is increasing in developed countries [1].

(C) Y. EREN, A. ÖZATA, M. KONUK, D. AKYIL, R. LIMAN, 2015
In traditional medicine, simultaneously applications of drugs that have different active contents have not prefered bacause of their interactions and adverse effects. But in phytotherapy, use of entire plant instead of purified active substances have provided synergistic effects or reducing in toxicity [2].

Turkey is very rich in endemic flora. Efficiency of these plants must be investigated about folk usage and safety. There are some reports about some Limonium species that have toxic effects. Some researchers found that Limonium nashii tanin extracts were caused to tumor formation [3]. In this study, it was aimed whether Limonium effusum (endemic for Turkey) species has cytotoxic and mutagenic effects.

Limonium genus belongs to Plumbaginaceae family which is represented with 6 genus and 68 species in Turkey and 24 genus and 800 species in the world [4]. Limonium species are halophyte plants resistant to drought and salinity [5]. Limonium species are called in Turkey population as «kunduz otu, eşekkulağı or deve kulağı».

The protein content of Limonium sinense is up to $14,81 \mathrm{~g} / 100 \mathrm{~g}$, total sugar $15,4 \mathrm{~g} / 100 \mathrm{~g}$, ash $13,01 \mathrm{~g} / 100 \mathrm{~g}$, while the fat content is low. In addition, it also contains a certain amount of vitamins, tannins, alkaloids, organic acids and flavonoids, and other substances. Limonium plant is rich in a variety of amino acids. The content of essential amino acids such as valine, threonine and phenylalanine is high [6].

Inorganic element analysis of Limonium plants with atomic absorption spectrophotometry showed that they were rich in inorganic elements, especially in trace elements. It was found that Limonium constant elements, $\mathrm{K}, \mathrm{Na}, \mathrm{Ca}, \mathrm{Mg}$ presented highly and $\mathrm{Ni}, \mathrm{Zn}, \mathrm{Cr}$, Co trace elements presented richly in Limonium plants [6]. 
Limonium species were rich in vitamins $\mathrm{C}, \mathrm{B}_{1}$, $\mathrm{B}_{2}, \mathrm{~B}_{12}$ and carotenoids. In addition, Limonium sinense also contains a certain amount of vitamin $\mathrm{D}$, and vitamin E [6].

It was found by using FTIR analysis that Limonium effusum contains myrcetin, menthol, thymol, carvacrol, and catechol in leaf methanol extracts and in root distilled water extracts. But in root methanol extracts, L. effusum contains rutin, syringic asit, ellagic, myrecetin, quercetin, flavanol [7].

Plant chemical compounds are the basic elements for drug industry. If plant compounds and their effects will discover anymore, the availability of producible drugs for human or animal health will be determined. For this purpose mutagenic and cytotoxic effects of aqueous extracts of $L$. effusum were investigated by using Ames, Allium and MTT tests.

Materials and methods. Plant Extraction. Limonium effusum (Boiss.) Kuntze was collected from Lake Ac1 (Afyonkarahisar, Turkey). Roots, stems and leaves of Limonium effusum were dried at room temperature $\left(25^{\circ} \mathrm{C}\right)$ and then powdered. Distilled water was used as a solvent. Extraction was performed according to Sofowora [8]. Extracts were used directly and freshly in test systems.

Allium Test. Onions (Allium cepa, $2 n=16$ ) were used in Allium test system. Allium test was achieved according to Fiskesjö [9] with a minor modification.

Determination of EC50 (Efficient Concentration). Five bulbs for all concentrations were rooted in distilled water for $24 \mathrm{~h}$. Then they were put into root, stem and leaf extracts of different concentrations and distilled water as a negative control for $96 \mathrm{~h}$. At the end of this time, root lengths were calculated and the root length of negative control group was compared with different concentrations of plant extracts.

Chromosome Aberration Test. Cell cycle of Allium cepa root meristematic cells was occurred in $24 \mathrm{~h}$ [10]. For this reason the chromosome aberration test was performed for 24, 48 and $72 \mathrm{~h}$ in all extracts. $\mathrm{EC}_{50}, \mathrm{EC}_{50} / 2$ and $2 \times \mathrm{EC}_{50}$ concentrations of extracts were used for 24,48 and $72 \mathrm{~h}$ treatment periods. Roots were fixed in Carnoy's fixative (3:1; methanol : glacial acetic acid) for $24 \mathrm{~h}$ at $4{ }^{\circ} \mathrm{C}$. The roots were stored in $70 \%$ alcohol. For the analysis the roots were taken from alcohol and were hydrolyzed in $1 \mathrm{~N} \mathrm{HCl}$ for $7 \mathrm{~min}$. Then the roots were washed in the distilled water for 15 min and stained in Feulgen dye for $1 \mathrm{~h}$ at room temperature.
Microscopic Study. Microscopic analyses included study of mitotic index, anaphase-telophase chromosome aberrations and other aberrations. For mitotic index (MI) study about 5000 cells were counted and MI\% was determined with the following formulation

MI\% = divided cell number/total cell number $\cdot 100$.

Other aberrations were determined along with MI study. For anaphase-telophase aberration study, about 500 cells were counted and laggard chromosomes, anaphase bridges, stickness, disordered anaphase-telophase aberrations were observed. $\mathrm{Ob}-$ tained data were evaluated with Oneway ANOVA, Duncan multiple comparison test at $\mathrm{p}<0.05$ level.

Ames Mutagenicity Test. S. typhimurium tester strains TA98 and TA100 were obtained from Hacettepe University, Turkey. While TA98 was used to determine the frame shift, TA100 was used to determine the base pair exchange.

S9 from rat liver (Sprague-Dawley), bacto agar, nutrient broth No. 2 (Oxoid), 2-aminoanthracene (2AA), $\beta$-nicotinamide-adenine dinucleotide phosphate ( $\beta$-NADP), glucose-6-phosphate (G6P), mitomycin-C (MMC), ampicillin, tetracycline, histidine and basic fuchsin were obtained from Sigma-Aldrich. Sodium azide (SA), citric acid monohydrate, $\mathrm{NaOH}, \mathrm{KCl}$ and $\mathrm{NaCl}$ were purchased from Riedel. 4-Nitro-o-phenylenediamine (NPD), 2-aminoanthracene (2AA) and 2-aminofluorene (2AF) were purchased from Fluka. Test substances: 0,$1 ; 1$; $10 ; 100 ; 1000 ; 10000 \mu \mathrm{g} /$ plate of Limonium effusum root, stemand leaf extracts were prepared. These concentrations were used freshly in Ames test.

Cytotoxic doses of the plants extracts $(10000$, $1000,100,10,1$ and $0,1 \mu \mathrm{g}$ /plate) were determined by the method of Dean et al. [11]. Ames test was performed as a standard plate incorporation assay with S. typhimurium strains TA98 and TA100 with or without metabolic activation [12]. Selection of the strains was based on the testing and strain selection strategies of Mortelmans and Zeiger [13]. These strains were tested on the basis of associated genetic markers. For each tester strain, a specific positive control was always used to test the experimental flaws, if any. While 4-nitro-o-phenylenediamine (NPD) was used for TA98 and sodium azide (SA) was used for TA100 as positive controls without metabolic activation. On the other hand, 2-aminofluorene (2AF) and 2-aminoanthracene (2AA) 
were used as positive controls with metabolic activation, for TA98 and TA100 strains, respectively. $500 \mu$ of $\mathrm{S} 9 \operatorname{mix}(500 \mu \mathrm{l}$ phosphate buffer added in without metabolic activation), $100 \mu \mathrm{l}$ of the plant extracts for each concentration and $100 \mu \mathrm{l}$ of a cell suspension from an overnight culture $(1-2 \times$ $\times 10^{9}$ cells $/ \mathrm{ml}$ ) were added to $2 \mathrm{ml}$ top agar (kept at $45{ }^{\circ} \mathrm{C}$ ) and vortexed for $3 \mathrm{~s}$. The entire mixture was overlaid on the minimal agar plate. The plates were incubated at $37{ }^{\circ} \mathrm{C}$ for $72 \mathrm{~h}$ and then the revertant bacterial colonies on each plate were counted. Positive controls and negative control (dis-

Table 1. Results of Allium cepa root growth inhibition test

\begin{tabular}{|c|c|c|}
\hline Doses, $\mathrm{g} / \mathrm{L}$ & $\begin{array}{c}\text { Mean Root } \\
\text { Length } \pm \text { SD }\end{array}$ & $\%$ Changes \\
\hline \multicolumn{3}{|c|}{ L. effusum root extracts } \\
\hline Control & $3,85 \pm 0,42^{a}$ & 100,00 \\
\hline 6,25 & $3,56 \pm 0,47^{b}$ & 92,47 \\
\hline 12,50 & $2,79 \pm 0,80^{\mathrm{c}}$ & 72,47 \\
\hline 15,00 & $2,62 \pm 0,33^{d}$ & 68,05 \\
\hline 20,00 & $1,98 \pm 0,22 \mathrm{e}$ & 51,43 \\
\hline 22,50 & $1,75 \pm 0,13^{\mathrm{f}}$ & 45,45 \\
\hline 25,00 & $1,42 \pm 0,49^{g}$ & 36,88 \\
\hline 37,50 & $1,49 \pm 0,31 \mathrm{~g}$ & 38,70 \\
\hline 50,00 & $1,18 \pm 0,19^{h}$ & 30,65 \\
\hline \multicolumn{3}{|c|}{ L. effusum stem extracts } \\
\hline Control & $3,85 \pm 0,42 \mathrm{ab}$ & 100,00 \\
\hline 6,25 & $3,73 \pm 0,69^{b}$ & 96,88 \\
\hline 12,50 & $3,97 \pm 0,58^{a}$ & 103,12 \\
\hline 25,00 & $3,40 \pm 0,66^{\mathrm{c}}$ & 88,31 \\
\hline 37,50 & $2,79 \pm 0,91^{\mathrm{d}}$ & 72,47 \\
\hline 50,00 & $2,56 \pm 0,59{ }^{\mathrm{e}}$ & 66,49 \\
\hline 65,00 & $1,98 \pm 0,19^{\mathrm{f}}$ & 51,43 \\
\hline 75,00 & $2,45 \pm 0,25 \mathrm{eg}$ & 63,64 \\
\hline 85,00 & $2,30 \pm 0,29^{g}$ & 59,74 \\
\hline \multicolumn{3}{|c|}{ L. effusum leaf extracts } \\
\hline Control & $3,85 \pm 0,42^{a}$ & 100,00 \\
\hline 6,25 & $3,47 \pm 0,92 \mathrm{~b}$ & 90,13 \\
\hline 12,50 & $3,14 \pm 0,47^{\mathrm{c}}$ & 81,56 \\
\hline 25,00 & $2,46 \pm 0,63^{d}$ & 63,90 \\
\hline 37,50 & $2,45 \pm 0,32^{d}$ & 63,64 \\
\hline 50,00 & $1,96 \pm 0,23^{\mathrm{e}}$ & 50,91 \\
\hline
\end{tabular}

Note. Small letters indicated statistically significant groups according to Duncan multicomparison test $(\mathrm{p}<0.05)$, SD - Standart deviation. tilled water) were concurrently maintained. Samples were tested on triplicate plates in three independent parallel experiments.

MTT Assay was performed with MDBK cells (Madin-Darby Bovine Kidney) (Sigma) according to Mosmann [14] and the test was repeated three times.

MDBK (Madin-Darby Bovine Kidney) (Sigma) cells that was used in this study, were incubated in $10 \%$ fetal bovine serum and $90 \%$ EMEM (Eagle's Minimum Essential Medium, Sigma) which included Earle's BSS Balanced Salt Solution), $2 \mathrm{mM}$ L-glutamin, 0,1mM non-essential amino acids and 1,5 g/L sodium bicarbonate. Cells that were incubated at $37{ }^{\circ} \mathrm{C}$ in $5 \% \mathrm{CO}_{2}$ incubator, removed from the bottom of the flasks by trypsinEDTA (Sigma) when they covered whole or $90 \%$ of flask surface. Cells, stained by trypan blue (Sigma), were counted three times with thoma slide and sufficient amount of cells was added (with medium solution, total $100 \mu$ l) to 96 -well cell culture plates for MTT test. Cells were incubated at $37{ }^{\circ} \mathrm{C}$ for $24 \mathrm{~h}$ in order to adhere to the bottom of the plates. At the end of this incubation time, the medium was removed from the wells. In order to determine the cytotoxic effects, different concentrations of plant extracts with freshly prepared medium were added to the wells and plates were incubated about $24,48,72,96 \mathrm{~h}$ at $37^{\circ} \mathrm{C}$ in $\mathrm{CO}_{2}$ incubator. Distilled water was used as a negative control group, and $50 ; 25 ; 12,5 ; 6,25 ; 3,125 \mu \mathrm{g} / \mathrm{ml}$ concentrations of extracts were used for MTT test [14].

MTT analysis: test extracts were removed at the end of the incubation periods. Then cells were incubated with $5 \mathrm{mg} / \mathrm{ml}$ MTT solution (Sigma) about $2 \mathrm{~h}$ in $\mathrm{CO}_{2}$ incubator for transformation of MTT dye to formazan salt (not dissolve in water). At the end of this application, MTT dyes were removed and $100 \mu \mathrm{l}$ DMSO was added to the wells for solve the formazan salts that were only formed by alive cells. Plates were analyzed by ELISA reader at $540 \mathrm{~nm}$ wavelength. Cell proliferation of control group was accepted «0» [14].

Results. Allium root growth inhibition test. This study determined the $\mathrm{EC}_{50}$ value that was about $50 \%$ of control group root length $(3,85 \mathrm{~cm}) . \mathrm{EC}_{50}$ values of root, stem and leaf extracts were found as 20, 65 and $50 \mathrm{~g} / \mathrm{L}$, respectively. Root length change of control group (\%) was accepted $100 \%$ and the other concentrations were compared with 
Table 2. Mitotic index (MI) and aberration (\%) results of Limonium effusum root, stem and leaf aqueous extracts

\begin{tabular}{|c|c|c|c|c|c|c|c|}
\hline $\begin{array}{l}\text { Concentration, } \\
\mathrm{g} / \mathrm{L}\end{array}$ & MI\% & $\begin{array}{l}\text { Anafaz } \\
\text { bridges }\end{array}$ & $\begin{array}{l}\text { Laggard } \\
\text { chro- } \\
\text { mosome }\end{array}$ & $\begin{array}{c}\text { Disorder- } \\
\text { ed ana- } \\
\text { phase- } \\
\text { telo- } \\
\text { phase }\end{array}$ & $\begin{array}{l}\text { Sticky } \\
\text { chromo- } \\
\text { some }\end{array}$ & $\begin{array}{l}\text { Total aberrations } \\
\quad(\% \pm \mathrm{SD})\end{array}$ & $\begin{array}{c}\text { Other aberrations } \\
\% \pm \mathrm{SD}\end{array}$ \\
\hline \multicolumn{8}{|c|}{ Limonium effusum root MI and aberration results } \\
\hline Control $-24 \mathrm{~h}$ & $32,13 \pm 1,14^{\mathrm{ab}}$ & 2,6 & 3,4 & 9,2 & 1,4 & $16,6 \pm 1,6^{\mathrm{a}}$ & $0,23 \pm 0,18^{a}$ \\
\hline 10 & $33,76 \pm 2,03^{b}$ & 6 & 12 & 22,6 & 11,2 & $51,8 \pm 1,71^{\mathrm{b}}$ & $0,31 \pm 0,1^{\mathrm{a}}$ \\
\hline 20 & $23,76 \pm 3,4^{\mathrm{c}}$ & 6,34 & 18,18 & 6,79 & 23,05 & $54,34 \pm 1,56^{b}$ & $0,33 \pm 0,06^{a}$ \\
\hline 40 & $26,79 \pm 1,7^{\mathrm{ac}}$ & - & - & - & - & - & $0,12 \pm 0,08^{a}$ \\
\hline Control $-48 \mathrm{~h}$ & $31,61 \pm 1,01^{\mathrm{a}}$ & 3 & 3,2 & 8,4 & 1,4 & $16 \pm 1,22^{a}$ & $0,04 \pm 0,03^{a}$ \\
\hline 10 & $24,68 \pm 1,57^{b}$ & 3,2 & 4,6 & 10,4 & 18,6 & $36,8 \pm 2,88^{b}$ & $0,18 \pm 0,08^{a}$ \\
\hline 20 & $35,53 \pm 1,94^{\mathrm{a}}$ & - & - & - & - & - & $0,13 \pm 0,03^{a}$ \\
\hline 40 & $46,86 \pm 1,55^{\mathrm{c}}$ & 3,8 & 11,87 & 14,17 & 22,34 & $52,14 \pm 2,09^{\mathrm{c}}$ & $0,53 \pm 0,12^{b}$ \\
\hline Control $-72 \mathrm{~h}$ & $30,84 \pm 1,98^{a}$ & 8,4 & 5,8 & 7,2 & 12,4 & $33,8 \pm 1,11^{\mathrm{a}}$ & $0,23 \pm 0,11^{a}$ \\
\hline 10 & $31,15 \pm 1,42^{a}$ & 2,53 & 12,71 & 28,65 & 9,44 & $53,33 \pm 1,29^{b}$ & $0,25 \pm 0,04^{a}$ \\
\hline 20 & $37,34 \pm 1,45^{b}$ & 3,93 & 21,17 & 28,91 & 1,05 & $55,06 \pm 1,89^{b}$ & $0,20 \pm 0,02^{a}$ \\
\hline 40 & $40,78 \pm 0,62^{b}$ & 5,09 & 20,86 & 28,87 & 2,22 & $57,04 \pm 2,12^{b}$ & $0,15 \pm 0,03^{a}$ \\
\hline \multicolumn{8}{|c|}{ Limonium effusum stem MI and aberration results } \\
\hline Control $-24 \mathrm{~h}$ & $32,13 \pm 1,14^{a b}$ & 2,6 & 3,4 & 9,2 & 1,4 & $16,6 \pm 1,6^{\mathrm{a}}$ & $0,23 \pm 0,18^{a}$ \\
\hline 32.5 & $34,92 \pm 1,69^{\mathrm{a}}$ & 6,2 & 21,4 & 19,6 & 11,6 & $58,8 \pm 1,98^{\mathrm{b}}$ & $0,29 \pm 0,08^{a}$ \\
\hline 65 & $21,31 \pm 0,91^{b}$ & 5,92 & 14,23 & 12,54 & 14,37 & $47,06 \pm 1,8^{\mathrm{c}}$ & $0,1 \pm 0,09^{\mathrm{a}}$ \\
\hline 130 & $19,74 \pm 0,58^{b}$ & 3,46 & 22,73 & 12,57 & 14,06 & $52,82 \pm 1,66^{\mathrm{d}}$ & $0,12 \pm 0,08^{a}$ \\
\hline Control $-48 \mathrm{~h}$ & $31,61 \pm 1,01^{a}$ & 3 & 3,2 & 8,4 & 1,4 & $16 \pm 1,22^{a}$ & $0,04 \pm 0,03^{a}$ \\
\hline 32.5 & $35,21 \pm 1,15^{b}$ & 5,17 & 17,55 & 11,9 & 20,59 & $55,22 \pm 3,68^{b}$ & $0,14 \pm 0,18^{a}$ \\
\hline 65 & $39,87 \pm 0,8^{\mathrm{c}}$ & 6,4 & 19,2 & 16,1 & 14,6 & $56,8 \pm 3,38^{b}$ & $0,36 \pm 0,17 \mathrm{~b}$ \\
\hline 130 & $37,14 \pm 0,65^{b c}$ & 6,2 & 21,4 & 11,8 & 15,4 & $54,8 \pm 2,88^{b}$ & $0,1 \pm 0,07^{\mathrm{a}}$ \\
\hline Control $-72 \mathrm{~h}$ & $30,84 \pm 1,98^{a b}$ & 8,4 & 5,8 & 7,2 & 12,4 & $33,8 \pm 1,11^{\mathrm{a}}$ & $0,23 \pm 0,11^{a}$ \\
\hline 32.5 & $32,18 \pm 1,67^{a}$ & 4,35 & 20,14 & 11,6 & 15,99 & $52,08 \pm 2,52^{b}$ & $0,05 \pm 0,1^{b}$ \\
\hline 65 & $27,38 \pm 0,14^{b}$ & 4,4 & 18,6 & 24,6 & 10,2 & $57,08 \pm 1,15^{\mathrm{c}}$ & $0,1 \pm 0,08^{a}$ \\
\hline 130 & $23,27 \pm 0,5^{c}$ & 4,8 & 21 & 32,6 & 12,6 & $71 \pm 1,37^{\mathrm{d}}$ & $0,2 \pm 0,1^{\text {a }}$ \\
\hline \multicolumn{8}{|c|}{ Limonium effusum leaf MI and aberration results } \\
\hline Control $-24 \mathrm{~h}$ & $32,13 \pm 1,14^{\mathrm{a}}$ & 2,6 & 3,4 & 9,2 & 1,4 & $16,6 \pm 1,6^{\mathrm{a}}$ & $0,23 \pm 0,18^{a}$ \\
\hline 25 & $38,95 \pm 1,37^{\mathrm{b}}$ & 1,68 & 9,86 & 8,38 & 27,97 & $47,89 \pm 1,72^{b}$ & $0,17 \pm 0,08^{a}$ \\
\hline 50 & $27,19 \pm 0,82^{\mathrm{c}}$ & 4,03 & 9,57 & 9,78 & 19,71 & $43,09 \pm 0,72^{\mathrm{c}}$ & $0,02 \pm 0,07^{b}$ \\
\hline 100 & $28,16 \pm 1,16^{\mathrm{c}}$ & 4,24 & 10,37 & 9,12 & 15,6 & $39,33 \pm 1,49^{\mathrm{c}}$ & $0,07 \pm 0,05^{b}$ \\
\hline Control $-48 \mathrm{~h}$ & $31,61 \pm 1,01^{\text {a }}$ & 3 & 3,2 & 8,4 & 1,4 & $16 \pm 1,22^{a}$ & $0,04 \pm 0,03^{a}$ \\
\hline 25 & $29,17 \pm 1,25 \mathrm{ab}$ & 7,2 & 9,4 & 28,4 & 11,2 & $56,2 \pm 2,78^{b}$ & $0,21 \pm 0,1^{\mathrm{b}}$ \\
\hline 50 & $26,37 \pm 1,21^{b}$ & 6,74 & 23,01 & 16,91 & 13,48 & $60,14 \pm 2,22 \mathrm{~b}$ & $0,35 \pm 0,16^{b}$ \\
\hline 100 & $21,34 \pm 0,51^{\mathrm{c}}$ & 4,74 & 24,81 & 13,71 & 13,69 & $56,95 \pm 1,84^{b}$ & $0,22 \pm 0,09^{b}$ \\
\hline Control $-72 \mathrm{~h}$ & $30,84 \pm 1,98^{\text {a }}$ & 8,4 & 5,8 & 7,2 & 12,4 & $33,8 \pm 1,11^{\mathrm{a}}$ & $0,23 \pm 0,11^{a}$ \\
\hline 25 & $28,73 \pm 0,91^{\mathrm{a}}$ & 3,07 & 19,69 & 10,57 & 17,1 & $50,43 \pm 1,31^{\mathrm{b}}$ & $0,13 \pm 0,1^{\mathrm{a}}$ \\
\hline 50 & $37,74 \pm 0,85^{b}$ & 2,14 & 5,21 & 19,84 & 19,94 & $47,13 \pm 3,34^{b}$ & $0,06 \pm 0,11^{\mathrm{b}}$ \\
\hline 100 & $41,44 \pm 0,7^{\mathrm{c}}$ & 3,22 & 5,75 & 11,92 & 19,12 & $40,01 \pm 1,33^{\mathrm{c}}$ & $0,04 \pm 0,07 \mathrm{~b}$ \\
\hline
\end{tabular}

Note. Small letters indicated statistically significant groups according to Duncan multicomparison test $(\mathrm{p}<0.05)$, SD - Standart deviation. 
this group. The maximum inhibition $(30,65 \%)$ of root growth was found in $50 \mathrm{~g} / \mathrm{L}$ concentration of L. effusum root extracts. On the other hand the unique increase $(103,12 \%)$ on root growth was determined in $12,5 \mathrm{~g} / \mathrm{L}$ concentration of $L$. effusum stem extracts. So these results have showed that $L$. effusum extracts in most of the concentrations have cytotoxic effects on root growth. Obtained data are given in Table 1 , and they were statistically evaluated by Oneway Anova Duncan multicomparison test, and the groups were defined in different small letters.

Mitotic index study was performed in order to observe the cytotoxicity of plants extracts. For this study we counted about 5000 cells for each concentration and all extracts were compared with control group. According to the results, 20 and $40 \mathrm{~g} / \mathrm{L}$ concentrations of $L$. effusum root aqueous extracts inhibited the root growth in $24 \mathrm{~h}$ treatment but in other treatment times these concentrations increased the root growth. So it was found that there was not any similarity in treatment periods.

$32,5 \mathrm{~g} / \mathrm{L}$ concentration of $L$. effusum stem aqueous extract increased the growth in all treatment times. But other higher concentrations decreased growth of the roots except 48 h. L. effusum leaf aqueous extracts did not show proportional increase or decrease. All data about MI of $L$. effusum aqueous extracts are given in Table 2.

Determination of chromosome aberrations: this study was performed in two steps. At the first step, 500 anaphase-telophase cells were observed, and aberrations (sticky chromosomes, anaphase bridges, laggard chromosomes and disordered anaphasetelophase) were determined. At the second step, 5000 cells were observed for each concentration, and C-mitosis, polyploidy and binuclear cell abnormalities were detected. As a result there was no

Table 3. Ames test results of aqueous extracts

\begin{tabular}{|c|c|c|c|c|c|}
\hline \multirow{2}{*}{ Test Materials } & \multirow{2}{*}{$\begin{array}{l}\text { Concentration, } \\
\mu \mathrm{g} / \text { plate }\end{array}$} & \multicolumn{4}{|c|}{ Mean colony numbers \pm SD } \\
\hline & & TA98 S9(-) & TA98 S9(+) & TA100 S9(-) & TA100 S9(+) \\
\hline \multirow{5}{*}{$\begin{array}{l}(-) \text { Control } \\
\text { SA } \\
2 \mathrm{AA} \\
2 \mathrm{AF} \\
\text { NPD }\end{array}$} & - & $280 \pm 3,08$ & $33 \pm 3,61$ & \multirow{5}{*}{$\begin{array}{c}115,6 \pm 0,89 \\
1622,8 \pm 11,63 *\end{array}$} & $123,2 \pm 1,64$ \\
\hline & 10 & & & & \\
\hline & 5 & & & & $2647 \pm 4,69 *$ \\
\hline & 200 & & $2752 \pm 43,24 *$ & & \\
\hline & 200 & $2514 \pm 39,75 *$ & & & \\
\hline \multirow[t]{5}{*}{ L. effusum root } & 1000 & $22,2 \pm 2,17$ & $37 \pm 3,81$ & $147,4 \pm 1,52 *$ & $119,2 \pm 1,30 *$ \\
\hline & 100 & $24,4 \pm 7,92$ & $31,4 \pm 1,95$ & $123 \pm 0,71 *$ & $124,4 \pm 1,52$ \\
\hline & 10 & $29,2 \pm 0,84$ & $28,2 \pm 3,27$ & $126,6 \pm 1,67 *$ & $123 \pm 2,00$ \\
\hline & 1 & $31,4 \pm 2,88$ & $27,4 \pm 2,07$ & $131,4 \pm 1,52 *$ & $126,4 \pm 0,89$ \\
\hline & 0.1 & $27,2 \pm 2,49$ & $27,2 \pm 2,17$ & $115,4 \pm 1,52$ & $103 \pm 1,87 *$ \\
\hline \multirow[t]{6}{*}{ L. effusum stem } & 10000 & $35,4 \pm 2,70$ & $32,8 \pm 1,64$ & $205,8 \pm 2,17 *$ & $195,8 \pm 2,77 *$ \\
\hline & 1000 & $25,4 \pm 5,08$ & $30,2 \pm 2,39$ & $135 \pm 1,87 *$ & $105,6 \pm 4,04 *$ \\
\hline & 100 & $25,2 \pm 4,97$ & $27,4 \pm 2,70$ & $116,8 \pm 2,49$ & $116,4 \pm 2,07 *$ \\
\hline & 10 & $22,2 \pm 1,48$ & $27,2 \pm 1,92$ & $124,8 \pm 1,48 *$ & $113,6 \pm 2,07 *$ \\
\hline & 1 & $28,8 \pm 2,59$ & $25,6 \pm 2,70$ & $113,4 \pm 1,67$ & $112,2 \pm 0,84 *$ \\
\hline & 0.1 & $51,4 \pm 2,07 *$ & $29,4 \pm 2,41$ & $118,2 \pm 2,28$ & $107,8 \pm 1,92 *$ \\
\hline \multirow[t]{6}{*}{ L. effusum leaf } & 10000 & $37,2 \pm 1,92$ & $28 \pm 2,92$ & $147,4 \pm 1,67 *$ & $160 \pm 1,58 *$ \\
\hline & 1000 & $29,6 \pm 3,29$ & $27 \pm 2,12$ & $138,4 \pm 1,14 *$ & $125 \pm 2,55$ \\
\hline & 100 & $34,8 \pm 2,59$ & $27 \pm 2,55$ & $123,2 \pm 1,64 *$ & $122,2 \pm 1,30$ \\
\hline & 10 & $30,6 \pm 4,88$ & $25,4 \pm 2,07$ & $121,2 \pm 2,39$ & $106 \pm 0,71 *$ \\
\hline & 1 & $28,6 \pm 1,95$ & $26 \pm 1,58$ & $113,6 \pm 2,19$ & $106 \pm 1,00 *$ \\
\hline & 0.1 & $35,4 \pm 2,30$ & $30,2 \pm 1,92$ & $117,4 \pm 1,82$ & $109,6 \pm 0,55 *$ \\
\hline
\end{tabular}

* Indicates statistically significant values according to Dunnett-t test $(\mathrm{p}<0.05)$. Pozitive controls; SA - Sodium azide, 2AA - 2-aminoantracene, 2AF - 2-aminofluorene, NPD - 4-nitro-o-phenylendiamine, SD - Standart deviation. 
proportional increasing or decreasing in anaphasetelophase aberrations. Sticky chromosomes and laggard chromosomes were determined more than the other anaphase-telophase aberrations. It was not found any proportional or significant increasing or decreasing in the determination of other aberrations (C-mitosis, polyploidy and binuclear cell). Aberration data and statistical analysis obtained from Limonium effusum aqueous extracts are given in Table 2.

Ames test results was carried out for mutagenicity determination of the tested extracts. For this test histidine mutant strains of Salmonella typhymurium, TA98 and TA100 were used, and control group colony numbers were compared with the extracts. The extracts which caused two-fold increase in the colony number of control group were accepted as mutagenic ones. In case of dose-dependent increase in colony numbers, the extracts were accepted as weak mutagenic solutions [13].

As a result of cytotoxicity tests, it was found that only Limonium effusum $10000 \mu \mathrm{g} /$ plate root aqueous extract were cytotoxic against Salmonella typhymurium strains among six tested concentrations $(10000,1000,100,10,1$ and $0,1 \mu \mathrm{g} /$ plate). So this toxic concentration was not used in Ames test.

In Ames test, Limonium effusum root, stem and leaf aqueous extracts were used. 4-nitro-o-phenyendiamine (NPD), 2-aminofluorene (2AF), sodium azide (SA) and 2-aminoantracene (2AA) were used as a positive control for TA98 S9(-), TA98 S9(+), TA100 S9(-) and TA100 S9(+) respectively, while distilled water was used as a negative control group. In this test, extracts or concentrations were not found as mutagenic. Ames test was repeated three times both with and without S9 metabolic activation, and the data is given in Table 3.

MTT test that is based on mitochondrial activity, was performed with Limonium effusum extracts by MDBK cell lines for 4 days. In this study 50; $25 ; 12,5 ; 6,25$ and $3,125 \mu \mathrm{g} / \mathrm{ml}$ concentrations of Limonium effusum root, stem and leaf aqueous extracts were used while distilled water was used as a negative control group. The tests were repeated three times in 96-well plates for 24, 48, 72 and $96 \mathrm{~h}$. The extracts were applied on MDBK cell lines and results were obtained from the absorbance of alive cells that were calculated by ELISA reader for each treatment time. Percentages of prolifera-

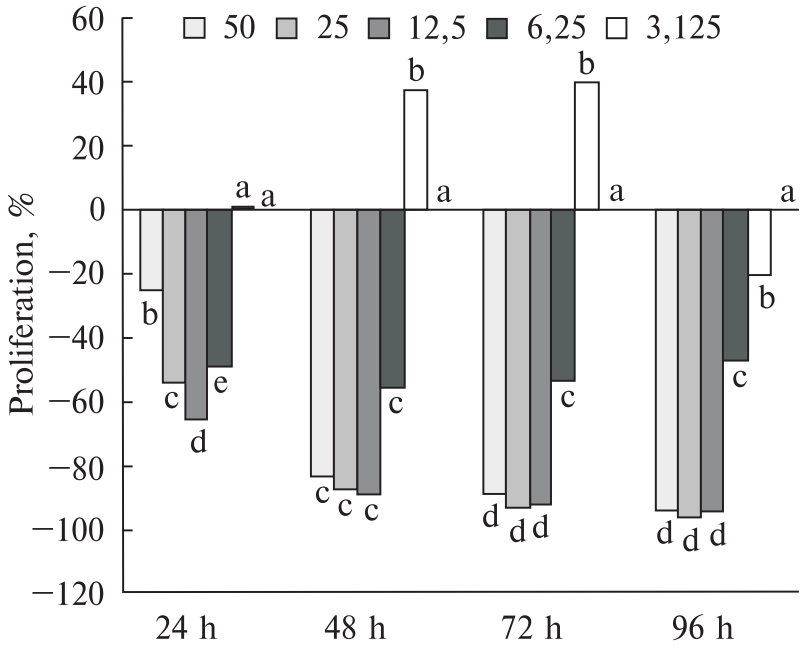

Fig. 1. Proliferation $\%$ of Limonium effusum root aqueous extracts. Here and in Fig. 2, 3 letters a, b, c, d, e indicated statistically significant groups according to Duncan multicomparison test $(\mathrm{p}<0.05)$

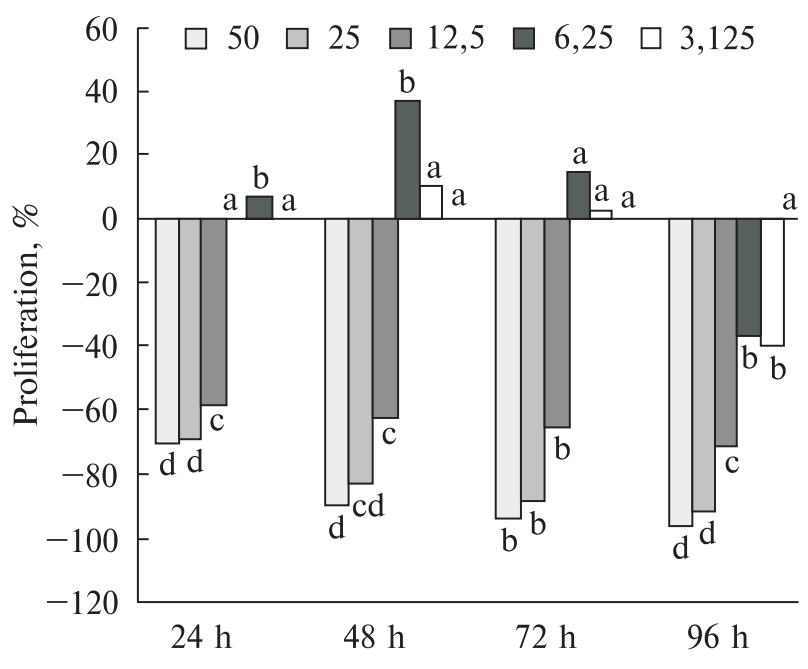

Fig. 2. Proliferation $\%$ of Limonium effusum stem aqueous extracts

tions (Proliferation \%) were calculated with the following formulation

Proliferation rates $\%=(\mathrm{B}-\mathrm{A}) \cdot 100 / \mathrm{A}[15]$.

A indicates the absorbance value of control group while B indicates the absorbance value of plant extracts.

$50 \mu \mathrm{g} / \mathrm{ml}$ concentration of $L$. effusum stem and leaf aqueous extracts decreased proliferation (about $96,23 \%$ ) more than the other extracts. L. effusum 6,25 and $3,125 \mu \mathrm{g} / \mathrm{ml}$ concentrations of leaf aque- 


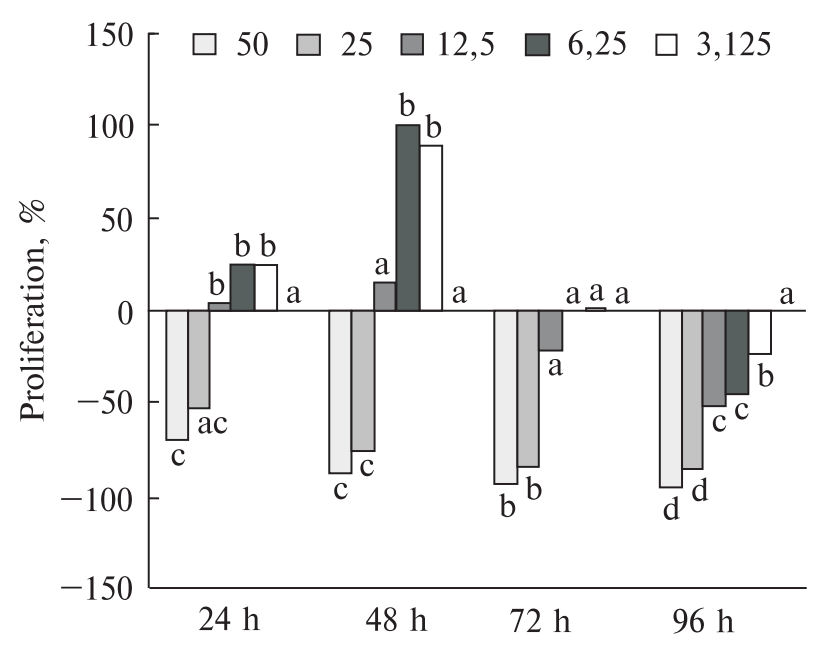

Fig. 3. Proliferation \% of Limonium effusum leaf aqueous extracts

ous extracts increased cell viability for $72 \mathrm{~h}$. The most increase in proliferation (about $100 \%$ ) was observed in $6,25 \mu \mathrm{g} / \mathrm{ml}$ concentration of leaf extract. All results of MTT tests are given in Fig. 1-3.

Discussion. «Plants make drugs» perception have caused to take no account of toxic effects of plants. On the other hand, some natural plant solutions may cause acute toxicity in long-term toxic effects. These toxic effects may generate diarrhea, sensitivity to allergens, nausea, vomiting, organtargeted toxicity, immunotoxicity, embryo and prenatal toxicity, mutagenicity, hepatotoxicity and nephrotoxicity in the present of epilepsy forming compounds, cardiac toxins and carcinogenic toxins. [16]. It was noticed that some of Limonium species were poisonous and toxic, too. For example Limonium tataricum and Limonium brasiliensis are in the international poisonous plants list [17]. Because of these facts, investigation of the negative effects of plant extracts has become very important.

In this study, mutagenic and cytotoxic effects of Limonium effusum (endemic for Turkey) were tried to be determined. The study was carried out with three test systems; bacterial test (Ames test), plant test (Allium test) and mammalian cell test (MTT test). Mutagenicity and cytotoxicity studies were previously achieved by these methods [18-23].

Limonium effusum is of Plumbaginaceae family and has specific chemical contents. Some of them are epigallocatechin, gallocatechin, menthol, thymol, carvacrol, cafeic acide, flavanols, quinons, rutin, rutinosit, myrcetin, citric acide, ellagic, quer- cetin, tannins and coumarins [7]. It was reported in different studies that naphtoquinons specific to Plumbaginaceae family were very important components. Cytotoxic effects of naphtoquinons based on reactive oxygen species (ROS) formation, mitochondria disorders and inhibition of timine binding to DNA [24, 25].

Toxicity and mutagenicity may be observed by Allium test. Toxicity was determined easily by root growth inhibition while mutagenicity correlated with chromosome breaks [9]. If water was used as a control group in the Allium test, the toxic ions (such as $\mathrm{Cu}$ and $\mathrm{Ca}$ ) must be removed from water [9], so distilled water was used as a control group in our study. In this test, the concentration that reduced the mitotic index of control group by half was accepted as cytotoxic limit value [26]. $\mathrm{EC}_{50}$ values of Limonium effusum and root, stem and leaf aqueous extracts were found to be 20,65 and $50 \mathrm{~g} / \mathrm{L}$, respectively. In general, there was a correlation between root growth and extract concentration. The most root growth inhibition $(30,65 \%$ change) was determined in $50 \mathrm{~g} / \mathrm{L}$ concentration of Limonium effusum root extract when compared to the control group.

Root growth inhibition always correlated with the decreasing in the number of dividing cells [20]. Root growth inhibition could occur due to the heavy metals of extracts. It was determined that some plants included metals like manganese $(\mathrm{Mn})$, cadmium $(\mathrm{Cd})$ and lead $(\mathrm{Pb})[27,28]$ and these metals effected the root growth inhibition of Allium cepa $[18,29,30]$. It was determined that Limonium species included copper $(\mathrm{Cu})$, zinc $(\mathrm{Zn})$, manganese $(\mathrm{Mn})$, chromium $(\mathrm{Cr})$ and iron $(\mathrm{Fe})$ [31]. Toxic effects results obtained from this study may be based on these elements.

As a result of the mitotic index studies by $\mathrm{Al}$ lium test, dose-dependent increasing or decreasing were not found contrarily to root growth inhibition test. The lowest mitotic index value $(19,74 \%)$ was found in $130 \mathrm{~g} / \mathrm{L}$ concentration of $L$. effusum stem extract. As a result of chromosome aberrations test, sticky chromosomes, anaphase bridges, laggard chromosomes and anaphase-telophase disruptions were highly determined in high concentrations. The other abnormalities (C-mitosis, polyploidy and binuclear cell) were found rarely.

Stickiness occurred by formation of subchromatide linkages that was the result of nested inter- 
chromosomal chromatin fibers [32]. Some studies reported that sticky chromosomes were the most encountered aberrations [33]. Sticky chromosomes indicate high toxicity, and this is irreversible. This aberration may cause cell deaths [34]. Laggard chromosomes were expressed with aneuploidy. $\mathrm{C}$-mitosis occurred as a result of inactivation of spindle fibers and had weak, reversible mutagenic effects. [18].

Plant alkaloids caused to spindle fiber disruptions [35], and Limonium genus includes alkaloids, too [6]. Also, naphtoquinons (plumbagin) that is the specific alkaloid to Plumbaginaceae family, are presented highly in Limonium species and have cytotoxic effects. Plumbagin acts as a mitotic inhibitor on onion roots. This inhibition effects were expressed with mitotic abnormalities like polyploidy, micronucleus, anaphase bridges, stickiness and laggard chromosomes [36]. This study showed that anaphase bridges, sticky chromosomes and laggard chromosomes were highly found and these anomalies could be derived from this component.

Ames test is commonly used with plant extracts for possible gene mutation determination. Positive results in any bacterial strains with and without metabolic activation are sufficient to identified a substance as a mutagen [37].

Ames test was done with the aqueous extracts of Limonium effusum roots, stems, and leaves, and generally mutagenicity was not found. In Ames test with TA98 S9 (+), Limonium effusum root extracts showed some weak mutagenic effect. Ames tests with plumbagin (naphtoquinon) have not shown any mutagenicity with TA98 and TA100 strains without metabolic activation. On the other hand the tests with metabolic activation have indicated inconsistent results [38, 39, 40, 41]. Mutagenicity tests with Escherichia coli WP2/pKM101 and WP2uvrA/pKM101 strains did not show mutagenic activity, but tests with AQ634 strain with S9 enzyme system showed mutagenic effects [42, 43]. Hydroxyl derivates of naphtoquinons showed mutagenic activity in $S$. typhimurium TA2637 and TA98 strains but it was found that they were not mutagenic in S. typhimurium TA100 strains [38].

MTT test with MDBK cell lines was used to determine the cytotoxicity of $L$. effusum aqueous extracts. It was noticed that MTT (tetrazolium blue) colorimetric analysis could be used with plant extracts for determination of reductions in cell culture viability studies [44]. It was evaluated that cell proliferation could be determined by MTT [14].

Ali et al. [45] reported that $615,1 \mu \mathrm{g} / \mathrm{ml}$ concentration of Limonium sokotranum leaf aqueous extract was found moderately toxic by cytotoxicity test with human amniotic epithelial cell line (FL-cells). These investigators also emphasized that cytotoxic effects of Limonium genus could be the reason of traditionally usage as antifungals. In this study, we used maximum $50 \mu \mathrm{g} / \mathrm{ml}$ concentration of Limonium effusum extracts and generally high concentrations have cytotoxic effects but low doses increased the cell proliferation.

Santhakumari et al. [46] investigated the effects of plumbagin on chicken embryo fibroblast cultures. It was found that the dominant effects of plumbagin reduced cell growth, cell proliferation and mitotic index. These researchers reported that, plumbagin acted as a poison of spindle fibers in low concentrations but in high concentrations it had nucleotoxic or cytotoxic effects. Also plumbagins can induce reactive oxygen species, apoptosis and inhibition of cell cycle. In this research, many of the extracts were found cytotoxic, especially for 96-hour treatments. But low concentrations have positive activities on cells up to 72-hour treatment. Findings about nucleotoxic and cytotoxic effects of plumbagin were compatible with our Allium test chromosome aberration, mitotic index determination and cell viability study.

Limonium tetragonum (Thunb.) plant total ethanol extracts increased the cell viability about $114,92 \%$ by cell viability test that performed murine makrophage RAW 264,7 cells [47]. In this research, $6,25 \mu \mathrm{g} / \mathrm{ml}$ concentration of $L$. effusum leaf extracts increased the cell proliferation about $100 \%$.

As a result, mutagenicity and cytotoxicity of endemic Limonium effusum root, stem and leaf aqueous extracts were investigated by Ames, Allium and MTT tests. In Allium root growth inhibition test, there was an inverse ratio between concentrations and cytotoxicity. Root, stem and leaf extracts of Limonium effusum $\mathrm{EC}_{50}$ concentrations were 20, 65 and $50 \mathrm{~g} / \mathrm{L}$, respectively. It was observed that many of the extracts and concentrations reduced the mitotic index in different treatment periods. Extracts mostly caused sticky chromosomes, polar disorders, laggard chromosomes and anaphase bridges that 


\section{Y. Eren, A. Özata, M. Konuk et al.}

were based on spindle fiber disruptions. Similar to the mitotic index data, MTT test indicated that many of the extracts were cytotoxic to MDBK cell line. According to Ames test, it was found that root extracts of Limonium effusum had a weak mutagenic effect in TA98 strain with S9. The other extracts were not found as mutagenic ones in Ames test.

\section{ИЗУЧЕНИЕ МУТАГЕННОСТИ}

И ЦИТОТОКСИЧНОСТИ ВОДНЫХ

ЭКСТРАКТОВ LIMONIUM EFFUSUM C ПОМОЩЬЮ ALLIUM-, AMES- И МТТ-ТЕСТОВ

\section{Y.Eren, A. Özata}

В настоящее время растения или экстракты растений стали очень важными для альтернативной медицины. Растения и их экстракты имеют много терапевтических преимуществ, однако некоторые из них являются потенциально токсичными, мутагенными, канцерогенными и тератогенными. Корни, стебли и листья Limonium effusum, эндемичного вида Турции, были изучены в этой работе. Мутагенные и цитотоксические эффекты водных экстрактов корней, стеблей и листьев Limonium effusum были изучены с помощью Allium-теста, теста Эймса и МТТ-теста. Тест на ингибирование роста корней лука и определение митотического индекса показали, что водные экстракты имеют дозозависимый токсичный эффект. При изучении хромосомных аберраций обнаружено большое количество таких аномалий, как слипшиеся хромосомы, нарушения анафазы-телофазы и отставшие хромосомы. Тест Эймса, проведенный на водных экстрактах корней Limonium effusum, показал слабо выраженный мутагенный эффект по отношению к Salmonella typhimurium, штамм TA98 c S9. MTT-тест, основанный на митохондриальной активности, показал, что большинство экстрактов имели цитотоксические эффекты. Цель этого исследования изучить возможные мутагенные и цитотоксические эффекты водных экстрактов L. effusum с использованием бактериальных, растительных клеток и клеток млекопитающих. Определенные низкие концентрации экстрактов L. effusum ингибировали цитотоксические эффекты, а высокие концентрации индуцировали цитотоксичность. Слабая мутагенная активность была определена только при помощи теста Эймса с TA98 S9(+).

\section{REFERENCES}

1. Saad B., Dakwar S., Said O. et al. Evaluation of medicinal plant hepatotoxicity in co-cultures of hepatocytes and monocytes // Evid. Based Compl. Alternat. Med. - 2006. - 3, № 1. - P. 93-98.

2. Poppenga R.H. Herbal medicine : Potential for intoxication and interactions with conventional drugs // Clin. Tech. Small Pract. - 2002. - 17, № 1. - P. 6-18.
3. Barnes W.S., Kiekowski E.J.Jr. Testing the environment for dispersed mutagens: use of plant bioconcentrators coupled with microbial mutagen assays // Environ. Health Perspect. - 1978. - 27, № 1. - P. 61-67.

4. Flora of Turkey and the East Aegean islands / Eds P.H. Davis et al. - Edinburgh : Univ. press, 1982. Vol. 7. - P. 465-477.

5. Zia S., Khan M.A. Effect of light, salinity, and temperature on seed germination of Limonium stocksii // Can. J. Bot. - 2004. - 82, № 2. - P. 151-157.

6. Zhen-fa X., Liang Z. Limonium sinense in mice with hemorrhagic anemia - Limonium sinense main component analysis // J. Shantou. Univ. - 1991. - 6, № 1. - P. 78-83.

7. Avaz $S$. Afyonkarahisar'da doğal olarak yetişen $L i$ monium Mill. türlerinin antimikrobiyal aktiviteleri // Master Thesis. Afyon Kocatepe University, Institute of Science. - 2010. Afyonkarahisar, Turkey.

8. Sofowora A. The state of medicinal plants research in Nigeria // Proc. of workshop held at Ile-Ife. - Nigeria, 1999. - P. 1-373.

9. Fiskesjö G. The Allium as a standard in environmental monitoring // Hereditas. - 1985. - 102. - P. 99-102.

10. Elçi S. Sitogenetikte Gözlemler ve Araştırma Yöntemleri // Firat University, Science Faculty Publica-

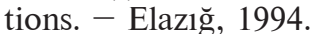

11. Dean B.J., Brooks T.M., Hodson-Walker G., Hutson D.H. Genetic toxicology testing of 41 industrial chemicals // Mutat Res. - 1985. - 153, № 1/2. - P. 57-77.

12. Maron D.M., Ames B.N. Revised methods for the Salmonella mutagenicity test // Mutat. Res. - 1983. 113, № 3/4. - P. 173-215.

13. Mortelmans K., Zeiger E. The Ames Salmonella/microsome mutagenicity assay // Mutat. Res. - 2000. 455, № 1/2. - P. 29-60.

14. Mosmann T. Rapid colorimetric assay for cellular growth and survival: application to proliferation and cytotoxicity assays // J. Immunol. Meth. - 1983. 65, № $1 / 2$. - P. 55-63.

15. Seo Y., Lee H.J., Kim Y.A. et al. Effects of several salt marsh plants on mouse spleen and thymus cell proliferation using MTT assay // Ocean Sci. J. - 2005. 40, № 4. - P. 209-212.

16. Smolinske S.C. Herbal product contamination and toxicity // J. Pharm. Pract. - 2005. - 18, № 3. P. 188-208.

17. Wagstaff D.J. International Poisonous Plants Checklist. - CRC Press, 2008. - 464 p.

18. Fiskesjö $G$. Allium test for screening chemicals; evaluation of cytologic parameters // Plants for Environmental Studies / Eds W. Wang, J.W. Gorsuch, J.S. Hughes. - New York, 1997. - P. 308-333.

19. Bakare A.A., Wale-Adeyemo A.R. The mutagenic and cytotoxic effects of leachates from domestic wastes and Aba-Eku landfill Nigeria on Allium cepa // J. Nat. Environ. Pollut. Technol. - 2004. - 3, № 4. - P. 455-462.

20. Babatunde B.B., Bakare A.A. Genotoxicity screening 
of waste water from Agbara Industrial estate Nigeria evaluated with the Allium cepa test // Poll. Res. 2006. - 25. - P. 227-234.

21. Ayim J.A., Bayor M.T., Phillips R.M. et al. The evaluation of selected Ghanaian medicinal plants for cytotoxic activities // J. Sci. Technol. - 2007. - 27, № 3. - P. 16-24.

22. Akitonwa A., Awodele O., Afolayan G., Coker H.A. Mutagenic screening of some commonly used medicinal plants in Nigeria // J. Ethnopharmacol. 2009. - 125, № 3. - P. 461-470.

23. Mahavorasirikul W., Viyanant V., Chaijaroenkul $W$. et al. Cytotoxic activity of Thai medicinal plants against human cholangiocarcinoma, laryngeal and hepatocarcinoma cells in vitro // BMC Comp. Altern. Med. - 2010. - 10. - P. 55

24. Aithal B.K., Kumar M.R., Rao B.N. et al. Juglone, a naphthoquinone from walnut, exerts cytotoxic and genotoxic effects against cultured melanoma tumor cells // Cell Biol. Int. - 2009. - 33, № 10. - P. 1039-1049.

25. Babula P., Adam V., Kizek R. et al. Naphthoquinones as allelochemical triggers of programmed cell death // Environ. Exp. Bot. - 2009. - 65, № 2/3. - P. 330-337.

26. Sharma C.B.S.R. Plant meristems as monitors of genetic toxicity of environmental chemicals // Curr. Sci. - 1983. - 52, № 3. - P. 1000-1002.

27. Ajasa A.M.O., Bello M.O., Ibrahim A.O. et al. Heavy trace metals and macronutrients status in herbal plants of Nigeria // J. Food. Chem. - 2004. - 85, № 1. - P. 67-71.

28. Haider S., Naithani V., Barthwal J., Kakkar P. Heavy metal content in some therapeutically important medicinal plants // Bull. Environ. Contam. Toxicol. 2004. - 72, № 1. - P. 119-127.

29. Boroffice R.A. Cytogenetic effects of zinc and chromium on the of onion (Allium cepa) root tip // Niger. J. Nat. Sci. - 1990. - 1, № 2. - P. 75-79.

30. Lerda D. The effect of lead on Allium cepa L. // Mutat. Res. - 1992. - 281, № 3. - P. 89-92.

31. Xiuyun L., Xian Y.J. Limonium bicolor and other four kinds of herbal medicine to stop bleeding in the determination of trace elements // Northwest. Pharma. J. - 1991. - 6, № 1. - P. 16-21.

32. McGill M., Pathak S., Hsu T.C. Effect of ethidium bromide on mitosis and chromosomes: a possible material basis for chromosome stickiness // Chromosoma. - 1974. - 47, № 2. - P. 157-166.

33. Ateeq B., Farah M.A., Ali M.N., Ahmad W. Clastogenicity of pentachlorophenol, 2,4-D and butachlor evaluated by Allium root tip test // Mutat. Res. 2002. - 514, № 1/2. - P. 105-113.

34. Badr A., Ghareeb A., El-Din H.M. Cytotoxicity of some pesticides in mitotic cells of Vicia faba roots // Egypt. J. Appl. Sci. - 1992. - 7. - P. 457-468.

35. Fasola T.R., Egunyomi A. Nigerian usage of bark in phytomedicine // Ethnobot. Res. Appl. - 2005. - 3. P. 73-77.

36. Krishnaswamy M., Purushothaman K.K. Plumbagin: A study of its anticancer, antibacterial and antifungal properties // Indian J. Exp. Biol. - 1980. - 18, № 8. - P. 876-877.

37. Zeiger E. Mutagens that are not carcinogenic: faulty theory or faulty tests? // Mutat. Res. - 2001. - 492, № $1 / 2$. - P. 29-38.

38. Matsushima T., Muramatsu M., Yagame O. et al. Mutagenicity and chemical structure relations of naturally occurring mutagens from plants // Progress in clinical and biological research. genetic toxicology of environmental chemicals. Part B. Genetic effects and applied mutagenesis / Eds C. Ramel et al. New York, 1986. - P. 133-140.

39. Durga R., Sridhar P., Polasa H. Antimutagenic activity of plumbagin in Ames Salmonella typhimurium test // Indian J. Med. Res. - 1992. - 96. - P. 143-145.

40. Hakura A., Mochida H., Tsutsui Y., Yamatsu K. Mutagenicity and cytotoxicity of naphthoquinones for Ames Salmonella tester strains // Chem. Res. Toxicol. - 1994. - 7, № 4. - P. 559-567.

41. Edenharder R., Tang $X$. Inhibition of the mutagenicity of 2-nitrofluorene, 3-nitrofluoranthene and 1-nitropyrene by flavonoids, coumarins, quinones and other phenolic compounds // Food Chem. Toxicol. 1997. - 35, № 3/4. - P. 357-372.

42. Farr S.B., Natvig D.O., Kogoma T. Toxicity and mutagenicity of plumbagin and the induction of a possible new DNA repair pathway in Escherichia coli // J. Bacteriol. - 1985. - 164, № 3. - P. 1309-1316.

43. Watanabe K., Sakamoto K., Sasaki T. Comparisons on chemically-induced mutation among four bacterial strains, Salmonella typhimurium TA102 and TA2638, and Escherichia coli WP2/pKM101 and WP2 uvrA/pKM101: Collaborative study II // Mutat. Res. - 1998. - 412, № 1. - P. 17-31.

44. Betancur-Galvis A., Saez J., Granados H. et al. Antitumor and antiviral activity of colombian medicinal plant extracts // Mem. Inst. Oswaldo Cruz. - 1999. 94, № 4. - P. 531-535.

45. Ali N.A.C., Mothana R., Ghaleb N., Lindequist U. Screening of traditionally used endemic Soqotraen plants for cytotoxic activity // Afr. J. Trad. Comp. Altern. Med. - 2007. - 4, № 4. - P. 529-531.

46. Santhakumari G., Saralamma P.G., Radhakrishnan N. Effect of plumbagin on cell growth \& mitosis // Indian J. Exp. Biol. - 1980. - 18, № 3. - P. 215-218.

47. Yang E., Yim E.Y., Song G. et al. Inhibition of nitric oxide production in lipopolysaccharide-activated RAW 264.7 macrophages by Jeju plant extracts // Interdiscip. Toxicol. - 2009. - 2, № 4. - P. 245-249.

Received 18.09.13 